\title{
„Nije na pjesniku da se klanja kralju”. Pozicija disidenta u hrvatskoj teatrologiji - slučaj Ivšić
}

\begin{abstract}
Petranović Martina, „Nije na pjesniku da se klanja kralju”. Pozicija disidenta u hrvatskoj teatrologiji - slučaj Ivšić (,It's not on the Poet to Bow to the King”. The Dissident's Position in Croatian Theatre Studies - the Ivšić Case). „Poznańskie Studia Slawistyczne” 6. Poznań 2014. Publishing House Science and Innovate, pp. 205-218. ISBN 978-83-63795-51-1. ISSN 2084-3011.

The paper discusses the position of Croatian playwright Radovan Ivšić in Croatian theatre historiography, before and after the independence of Croatia in the nineties. The research results point to three major phases in Ivšić's reception in Croatian theatre historiography - the rejection, acceptance and canonization.
\end{abstract}

Keywords: Radovan Ivšić; Croatian theatre; Croatian theatre studies; theatre historiography; dissident

\section{Ni crno ni crveno}

Prema definiciji disidenta u Velikome rječniku hrvatskoga jezika koja kaže da je disident, ,intelektualac u komunističkim režimima druge pol. 20. st. koji je otvoreno izražavao nezadovoljstvo društvenim prilikama i zbog toga bio na različite načine šikaniran i progonjen" (Anić 2003: 220), pjesnik i dramatičar Radovan Ivšić (1921-2009) može se smatrati paradigmatskim primjerom hrvatskoga književnog i kazališnog disidenta, no s jednom iznimkom ili dodatkom. Ivšić je, naime, bio podjednako nepoćudan u dva posve oprečna dvadesetostoljetna totalitarna režima - i profašističkom na snazi za vrijeme Nezavisne Države Hrvatske (1941-1945), kada i nastaje glavnina njegova opusa na hrvatskom jeziku, i u komunističkom, dominantnom u desetljećima nakon završetka Drugoga svjetskog rata do raspada SFR Jugoslavije. Razlika je bila u motivima, metodama i/ili dosezima 
proskribiranja njegova djela i djelovanja, a njegov se književni i životni nonkonformizam, opiranje instrumentalizaciji pjesnika i pjesništva te beskompromisna posvećenost stvaralačkoj slobodi u novijoj književnoj i kazališnoj historiografiji i publicistici nerijetko ističu kao jedna od svjetlijih točaka hrvatske književne i kazališne povijesti druge polovice 20. stoljeća, premda bi se i danas moglo govoriti o svojevrsnoj polarizaciji stručne i kulturne javnosti na njegove zagovornike i njegove osporavatelje, ne uvijek i posvema podudarne, ali ipak bliske polarizaciji na tzv. krležijance i one koji to nisu. U ovom će se radu ukratko razmotriti oblici, razlozi i mehanizmi neprihvaćanja Ivšićeva djela u oba perioda te utvrditi i proučiti momenti koji su vodili od njegove posvemašnje nevidljivosti četrdesetih, pedesetih i šezdesetih godina 20. stoljeća i doveli do prvih promjena u njegovoj kazališnoj i kazališnohistoriografskoj valorizaciji i vidljivosti još u vrijeme komunizma sedamdesetih i osamdesetih, no osnovni je cilj osvjetljavanje njegove pozicije u hrvatskoj teatrologiji i književnoj i kazališnoj historiografiji u postkomunističkom razdoblju nakon provedbe demokratskih izbora i osamostaljenja Republike Hrvatske, odnosno u proteklih dvadesetak godina.

Većina Ivšićeva dramskog opusa napisana u prvoj polovici četrdesetih (Daha 1940-1941., Kralj Gordogan 1943., Vane 1943., Sunčani grad 1944., Kapetan Oliver 1944. i Vodnik pobjednik 1944. te korska recitacija Narcis 1942.) u vrijeme svog nastanka ostala je netiskana i neizvedena, a gotovo cijela naklada Narcisa (1942) bila je zaplijenjena, navodno na Pavelićev zahtjev. Ivšić je u to vrijeme bio članom jedne od prvih neinstitucionalnih i neoficijelnih hrvatskih kazališnih skupina, Družine mladih, koja je, takoreći na rubu legalnosti, djelovala u četrdesetima te je nedugo nakon zaplijene izvela Narcisa u stanu vođe družine i njezina redatelja Vlade Habuneka, a neposredno nakon raspada NDH i oslobođenja Zagreba, već u lipnju 1945., izvela je i Ivšićev Sunčani grad i Vodnika pobjednika (pod naslovom Rojnik pobjednik), također u Habunekovoj režiji. Razlozi zbog kojih je Ivšićevo dramsko djelovanje u navedenom razdoblju bilo nepoželjno bili su dvojake prirode - političko-ideološke i poetičko-estetske. Otklonom od podržavanja govora vlasti nije se uklapao u poželjno idoliziranje vladajuće politike, što je napose uočljivo u Kralju Gordoganu u kojem se osuđuje i parodira svaki oblik totalitarizma, diktature jednog gledanja i kulta ličnosti. Također, svojim književnim postupcima - antimimetičkim i antiiluzionističkim načelima, destruiranjem klasičnog lika i klasične dramske forme, 
uvođenjem kora kao jednoga od težišta dramskog djela, propitivanjem suodnosa individualnoga i kolektivnoga, odbacivanjem tradicionalnog govora građanske drame i ideologiziranog diskursa u korist jezika oslobođenoga neposredne komunikacijske funkcije, rastvaranjem sintaktičkih obrazaca i pravopisnih normi - nije se uklapao ni u izražajne normative psihološke ili konverzacijske drame kakva se pisala i/ili igrala u kazalištu ni u realističke inscenacijske konvencije na snazi u tadašnjoj kazališnoj praksi.

U komunističkom režimu Ivšićeva su djela ponovno bila nepoželjna kako zbog šireg društvenog, kulturološkog i ideološkog razloga, odnosno zbog njegova načelnog nepristajanja na bilo kakvu utilitarnost književnog djela i kazališta, tako i zbog uže književnog/kazališnog razloga, odnosno razilaženja njegova dramskog rukopisa i proskribirane socrealističke poetike, i u sadržajnom i u formalnom pogledu. Prvi neposredni rezultati bile su zabrane spomenutih predstava Družine mladih prema Ivšićevim djelima Sunačni grad i Vodnik pobjednik, koje su skinute s repertoara usmenom službenom odlukom i zapečaćene negativnom kritikom Vjekoslava Kaleba u tjedniku Komunističke partije „Naprijed” pod naslovom Jedna zabluda u kojoj je osuđena i tematika Ivšićeva djela i scenski izričaj Družine mladih - od glume i scenskog pokreta do kostima. Potom je uslijedilo ,pretapanje” Družine u jezgru današnjega Zagrebačkog kazališta lutaka, neprihvaćanje Kralja Gordogana za tisak uz obrazloženje o potrebi realističkog i nealegoričnog izražavanja (Ivšić 2002: 110), a naposljetku i preporuke da stvori lik pozitivnog junaka u skladu s dominantnom poetikom socrealizma. Nakon tako zacrtanih pravila igre već krajem četrdesetih, unatoč tome što mu je tolerirana prevodilačka djelatnost, kao i adaptacije tekstova za lutkarsko kazalište, idućih nekoliko desetljeća objavljivanje i igranje Ivšićevih izvornih dramskih djela bilo je onemogućeno.

\section{Prva izdanja i izvedbe}

Uslijed sužavanja prostora njegova umjetničkog djelovanja Ivšić je sredinom pedesetih otišao u Francusku gdje je još za rata napisan Kralj Gordogan doživio radijsku izvedbu, javno čitanje i scensku provjeru ${ }^{1}$ te je 1968.

${ }^{1}$ Kralj Gordogan je izveden na francuskom radiju Chaîne nationale (1956) te na njemačkom Radio Köln (1962). Michel Bouquet čita ga na XVI. festivalu u Avignonu; 1969. 
i otisnut. Također, Kralj Gordogan i Daha su u knjizi John H. Matthewsa (1974) dobili i svoju prvu ozbiljniju teatrološku kontekstualizaciju u okviru rasprava o kazališnom dadaizmu i nadrealizmu. No do upoznavanja hrvatske stručne i kulturne javnosti s Ivšićevim opusom dolazi tek u sedamdesetim godinama, nakon tridesetogodišnjeg potiskivanja, prešućivanja ili otvorena nijekanja, prvo kroz poeziju, a potom i dramu, ponajprije zahvaljujući Zvonimiru Mrkonjiću koji je Ivšićeva djela otkrio, priređivao, tumačio i publicirao. Za dramski opus posebice je važna 1975. kada časopis „Prolog” objelodanjuje Kralja Gordogana, otpočinjući povijest tiskanja Ivšićevih dramskih djela, jer slijedi i skoro ukoričenje svih Ivšićevih dotad napisanih kazališnih djela, u Mrkonjićevu izboru i s Mrkonjićevim pogovorom, pod nazivom Teatar (1978). Tiskanjem njegovih djela otvoren je put i scenskim uprizorenjima koja su se ubrzo zaredala u profesionalnim i u amaterskim kazalištima. U Teatru \&TD izveden je Kralj Gordogan (1979), u Hrvatskom narodnom kazalištu u Zagrebu Aiaxaia ili moći reći (1983) napisana po narudžbi za to kazalište, a u Dramskom kazalištu Gavella Kapetan Oliver (1985), redom u režiji V. Habuneka. Od amaterskih i/ili studentskih izvedbi Ivšićevih djela početkom osamdesetih vrijedi istaknuti predstave Vane dubrovačkoga amaterskog kazališta Lero (1980), Vodnik pobjednik sisačkoga amaterskog kazališta Daska (1981), Daha Dramske grupe studentskog esperantskog kluba iz Zagreba te Akvarij (napisan 1956. u Francuskoj) Studentskog kazališta „Ivan Goran Kovačić” iz Zagreba (1982).

Višedesetljetna šutnja o Ivšiću imala je ozbiljne posljedice - nuđenjem poetičke alternative prihvaćenomu socrealističkom modelu Ivšić nije mogao utjecati na razvoj hrvatske drame ni na oblikovanje hrvatskoga kazališnog izričaja. Godina objavljivanja Gordogana stoga je važna i zbog članka Preobrazba farse jer Mrkonjić u njemu, polazeći od srednjovjekovne žanrovske odrednice, objašnjava model dramskog pisma karakterističan za suvremenu hrvatsku dramu tog razdoblja te pritom kao svojevrsnog rodonačelnika žanra ustoličuje upravo Ivšićeva Kralja Gordogana otvarajući mogućnost njegova smještanja u tradiciju i kanon hrvatske novije dramske produkcije koja je u prethodnim desetljećima propuštena (Mrkonjić 1975).

izveden je pred ruševnima dvorca Lacoste markiza de Sadea. Detaljni podaci o tiskanju i izvedbama Ivšićevih dramskih tekstova vidi u: Ivšić 2002. 
U Cindrićevu pokušaju povijesne sinteze hrvatskog teatra iz 1960. $H r$ vatski $i$ srpski teatar Ivšićevo se djelo i ime ne spominju, ali je zato zastupljen u Povijesti hrvatskoga kazališta Nikole Batušića iz 1978. Izašla u godini kada je Ivšićev dramski opus tek objelodanjen tiskom u Hrvatskoj, i kada je izvedbena povijest tek pred njim, ona Ivšića ipak jezgrovito i precizno locira u Družinu mladih prepoznajući njezin inovativan estetski pristup te u kontekst nadrealizma pripisujući mu jedinstvenost takvih nastojanja u okvirima hrvatskog kazališta (Batušić 1978: 340, 414). Daljnja kanonizacija Ivšića (napose Gordogana) nastavlja se sredinom osamdesetih uvrštavanjem njegovih djela u izbor antologijskih djela hrvatske književnosti u sklopu edicije Pet stoljeća hrvatske književnosti u izboru Branimira Donata i s predgovorom u kojem su istaknuta sva bitna poetička obilježja Ivšićeva dramskog opusa.

Prvi pokušaji pisanja o teatru Radovana Ivšića velikim su dijelom nastojali kontekstualizirati njegovo djelo u postojeću književnu i kazališnu tradiciju, domaću i inozemnu, dovodeći ga u vezu s različitim umjetničkim pravcima, poput nadrealizma (veći dio opusa), teatra apsurda (Akvarij) i kasnije postmodernizma (Aiaxaia) te ukazujući na brojne tradicijske i/ili intertekstualne poveznice Ivšićevih djela i različitih tekstova zapadne, istočne i narodne kulture. Zbog potonjega su mu pojedinci povremeno i odricali izvornost, no unatoč tome krajnji je zaključak ipak vodio $\mathrm{k}$ apostrofiranju jedinstvenosti Ivšićeve književne i kulturne pojave i njegove apartnosti u odnosu na postojeće oblike dramskog i kazališnog pisma i nemogućnosti njegova jednoznačna podvođenja pod bilo koji književni pravac, što će osobito doći do izražaja u posljednjih dvadesetak godina. Nakon prvih demokratskih izbora, osamostaljenja Republike Hrvatske, raspada Jugoslavije i totalitarističkog režima te rata devedesete i potom nulte godine novog milenija označile su i nove zaokrete u recepciji i valorizaciji Ivšićeva opusa.

\section{Nakon osamostaljenja}

Nakon odcjepljenja od jedne političke zajednice i utvrđivanja novog društveno-političkog uređenja u devedesetima, slično kao i u nizu europskih tranzicijskih zemalja na mijeni osamdesetih i devedesetih, nov osjećaj nacionalne slobode rezultirao je i nastojanjem da se vlastita nacionalna 
povijest, pa tako i književna i kazališna, revalorizira i rekonstituira u skladu s novonastalim okolnostima, dijelom i na tragu krilatice o reviziji povijesti iz aspekta pobjednika (Wilmer (ur.) 2004). Uobičajeno je tako bilo pisati o ,izgubljenima” ili iz različitih razloga prešućivanim tradicijama te o marginaliziranim i iz različitih razloga izostavljenim imenima, djelima i pojavama koje se godinama nisu željele/smjele spominjati. Drugo lice iste medalje bilo je i nastojanje osamostaljene nacionalne zajednice da provede institucionalizaciju i kanonizaciju svoje književne i kazališne kulture kroz povijesti književnosti, hrestomatije, enciklopedije te različite specijalizirane leksikone i priručnike. Obrat u razmišljanju potaknule su i promjene u promišljanju povijesti, sumnje u neupitnost povijesne istine i spoznaja da je i povijest svojevrstan oblik pripovjedne konstrukcije ili pripovijesti podložan različitim tumačenjima i uvelike oblikovan vrijednosnim sustavom i potrebama pozicije iz koje se povijest sagledava i (re)ispisuje (Worthen, Holland (ur.) 2003; Postlewait 2009; Canning, Postlewait (ur.) 2010; Bial, Magelssen (ur.) 2010).

Nakon osamostaljenja Republike Hrvatske napisane su dvije povijesti hrvatske književnosti u kojima je svoje mjesto dobio i Ivšić, ali u raznovrsnom opsegu, sadržaju i vrednovanju, često i u skladu sa svojim općim metodološkim pa i ideološkim polazištima. U Povijesti hrvatske književnosti Dubravka Jelčića iz 1997. (drugo dopunjeno izdanje iz 2004) R. Ivšić predstavljen je jednim odlomkom, mahom kao dio naraštaja nakon Drugoga svjetskog rata koji nije bio „u žarištu zbivanja” i koji je velikim dijelom ostao „u sjeni” književnika okupljenih oko časopisa „Krugovi” (Jelčić 2004: 486). Jelčić spominje zabranu Narcisa - bez eksplikacija razloga, a kad je riječ o dramskom opusu, navodi Ivšićevu bliskost nadrealizmu, eksperimentalni karakter njegova teatra i usmjerenost na jezik i odsustvo dramske strukture u klasičnom smislu, spominjući imenom tek zbirku Teatar iz 1978. i nekoliko njegovih djela na francuskom jeziku. Gordogan se, iako već u kazalištu i kazališnoj historiografiji ustoličen kao simbol Ivšićeva stvaralaštva, poimence ne izdvaja, a ne problematizira se ni izbivanje Ivšića s književne i kazališne scene nakon rata. Naprotiv, Povijest hrvatske književnosti Slobodana Prosperova Novaka iz 2003. mnogo više prostora i pozornosti posvećuje Ivšiću, svim aspektima njegova književnog opusa drama, poezija, eseji - ali i društvenim okolnostima njegova djelovanja ne libeći se odmah u uvodu naznačiti njegovu poziciju oponenta svim vrstama 
političkog i poetičkog totalitarizma i preskriptivnosti, pa i konkretnih posljedica koje mu je takva opredijeljenost donijela u oba totalitarna režima. Poimence se spominju i ukratko analiziraju te kontekstualiziraju (društveno i/ili kazališno) sva Ivšićeva dramska djela, a Kralju Gordoganu posvećena je posebna pozornost i u književnom aspektu i u društvenom kontekstu, kao i u teškom proboju do scene. U sklopu dosadašnjih sinteza hrvatske književnosti Novakova povijest jedina Ivšiću posvećuje dužnu pozornost, a nije nevažno spomenuti ni kako je upravo Novak smirivao strasti između polariziranih krležijanaca i ivšićevaca koje su se zahuktale nakon što je 2001. na teatrološkom simpoziju Krležini dani u Osijeku Ivšić izjavio da je Krleža najveća „katastrofa” koja se mogla dogoditi hrvatskoj književnosti zamjerajući mu konformizam spram vladajućeg režima nakon Drugoga svjetskog rata i nerazumijevanje modernih tendencija u umjetnosti druge polovice stoljeća (Ivšić 2002).

Nakon Batušićeve povijesti hrvatskog kazališta sličnih sintetskih pokušaja više nije bilo, no načinjeno je nekoliko antologija, vodiča i hrestomatija hrvatske dramske književnosti, a R. Ivšić je u njima varijabilno zastupljen. Već 1984. Ivšić je, s pobrojanim svim dramskim djelima i posebnim osvrtom na Gordogana, uvršten u Mrduljašev Dramski vodič, inače vrlo selektivan ,izbor iz hrvatske dramatike XX. stoljeća” u kojem je ukupno predstavljeno tek 27 autora, a Ivšić se našao i u ponovljenom izdanju vodiča iz 1997. godine. U Hećimovićevoj 1988. objavljenoj antologiji hrvatske dramske književnosti Ivšić nije zastupljen, što zbog usredotočenosti izbora na djela koja autor smatra kapitalnima i stilotvornima, što zbog uvjerenosti da njegovo najbolje dramsko djelo Kralj Gordogan i nije tolika novina nakon Jarryjeva Ubua. Zagovornik srodne teze bio je i Slobodan Selenić (1964), no mnogi raniji i kasniji radovi takve tvrdnje nastojali su modificirati dokazivanjem Ivšićeva višestrukog razmimoilaženja s Jarryjem. Ivšić je međutim zastupljen u Hrestomatiji novije hrvatske drame, II. dio (1941-1995) koju je 2001. načinio Boris Senker, Kraljem Gordoganom, napose u okviru tradicije hrvatske dramske farse - i to kao njezin predvodnik. B. Senker tom je prigodom istaknuo i ideološke i poetičke razloge Ivšićeva svojevremenoga marginaliziranja dajući i njegovog kratak analitički pregled, no posebno se važnim čini što je, dajući podrobnu analizu novorealističkoga i socrealističkoga dramskog modela (s formalnog, tematskog te utilitarnog i etičkog stajališta), ponudio i jasnu osnovu za kompariranje Ivšićeva raskoraka od 
onovremene „kazališne i dramske matrice” (Senker 2001: 14) ustvrdivši kako Gordogan dramaturški gledano nije imao nikakvog prethodnika ili uzor u nacionalnoj dramskoj književnosti (Senker 2001: 253). U nedavno objavljenoj antologiji hrvatske drame 20. stoljeća koju je Nataša Govedić priredila na francuskom jeziku Ivšić također nije izostao - kako zbog konceptualnih razloga autoričina izbora (naslov je Cirkuska parada) tako i zbog toga što je ipak riječ o autoru koji je obilježio poslijeratnu francusku književnost.

Ivšić je zastupljen i u gotovo svim relevantnim leksikonskim pregledima hrvatske književnosti nastalima u posljednja dva desetljeća. Leksikon hrvatskih pisaca iz 2000. (autorica jedinice je Mira Muhoberac) već vrlo neuvijeno progovara o Ivšićevu životopisu - zabranama, otkazima, prešućivanju pa i isključenju iz Društva književnika 1961. godine - ali i podrobno analizira poetičke kvalitete njegovih dramskih djela pokušavajući mu utvrditi nacionalni i inozemni kontekst i tradiciju s posebnim osvrtom na nadrealizam i osobitost njegove jezične fakture. Priređujući hrvatsko izdanje leksikona 500 drama. Vodič kroz svjetsku i domaću dramsku književnost (2002) Ana Lederer je među pedeset i pet izabranih hrvatskih dramskih djela uvrstila i Radovana Ivšića, odnosno njegova Kralja Gordogana, rukovodeći se pritom načelom odabira najpoznatijih i najznačajnijih tekstova pojedinih autora i razdoblja, kriterijem kazališne izvođenosti pojedinog djela te, kako i sama priznaje u uvodnom objašnjenju, željom da predstavi što veći broj autora druge polovice dvadesetog stoljeća, subjektivnim preferencijama i imajući u vidu prvenstveno školskog ili studentskog čitatelja kojemu je vodič namijenjen (Lederer 2002: 8). Tri godine poslije Ivšić je uvršten i u šesti svezak Hrvatskoga biografskoga leksikona (autor je Bruno Kragić) - projekt pokrenut s ciljem da prikaže životopise važnih pojedinaca rođenih do kraja 1945. godine ,koji su ostavili znatan trag u svojoj zemlji i svijetu", a u kojem se bez suvišnog ideologiziranja trezveno notiraju i sažimaju sva dosadašnja znanja o Ivšiću i njegovu djelu usredotočujući se na književne kvalitete i posebnosti Ivšićeva opusa, posebice na Kralja Gordogana. U Leksikon hrvatske književnosti - djela iz 2008. (autorica je Višnja Machiedo) uvrštena su čak tri Ivšićeva djela - Kralj Gordogan, Narcis te Aiaxaia ili moći reći - što svjedoči o potpunom ustoličenju Gordogana i Narcisa kao ključnih djela njegova stvaralaštva, ali i proširivanju na recentnije dramsko djelo Aiaxaia kojemu do tada nije toliko pridavana pozornost. 
Naposljetku, Ivšić je kao autor, te s dva djela koja su se formirala kao središnja u njegovu opusu (Gordoganom i Narcisom) zastupljen i u četverotomnoj Hrvatskoj književnoj enciklopediji (2010-2012), a odabir autorice Ane Prolić koja je o Ivšiću mnogo pisala, ali ga je zastupala i u praksi kao dramaturginja, najčešće u suradnji s redateljem Mariom Kovačem, ukazuje na usmjerenost inače dosta propitivane enciklopedije na poetičke više nego na političke implikacije Ivšićeva opusa.

Zasebna linija proučavanja Ivšićeva opusa nakon osamostaljenja usko je povezana s uže literarnim i kazališnim čimbenicima, odnosno s istraživanjem poetičkih odrednica njegova opusa, nerijetko i u kontekstu izmijenjenih, širih, postlogocentričnih i/ili postdramskih pogleda na definiciju i narav kazališta kao takvoga, osobito u kontekstu Ivšićeva zalaganja za dehijerarhiziranje izražajnih sredstava u kazalištu, za razvijanje teatra kao tjelesnog pisma u kojem su riječima ravnopravni glasovi, pokreti, prostor, svjetlost te za povećan udio kora kao identiteta razlike (Ivšić 2002). Prvi takav tekst o Ivšiću napisala je Jasna Denona, posvetivši se analizi njegova teatra u dvodijelnom članku Teatar Radovana Ivšića iz 1996. godine, poglavito iz vizure propitivanja avangardnosti Ivšićeva teatra u aktualnom trenutku i odmaka od isključivog promatranja Ivšićeva opusa u kontekstu nadrealizma, kao što je to do tada često i nekritički činjeno, odnosno iz aspekta specifične Ivšićeve inačice nadrealizma (Denona 1996a: 19).

U godini kada se stidljivo obilježavala 80 . obljetnica Ivšićeva rođenja nekoliko članaka i radova poslije objedinjenih u knjizi Dubinski rez (2012) napisao je Darko Gašparović s ciljem analize Ivšićeva dramskog opusa i kazališne poetike u cjelini, ali i apostrofiranja Aiaxaie kao prvoga hrvatskog postmodernističkog dramskog teksta te pledoajea za izvođenje Ivšića u kazalištu. U prvoj polovici prvog desetljeća novog milenija proučavanja Ivšićeva opusa s dotad nepoznatom sveobuhvatnošću prihvatila se Ana Prolić. Navedena je autorica analizirala pojedina Ivšićeva djela iz aspekta suvremenih teorija - primjerice Sunčani grad kao ikonoklastičku utopiju, obarajući neke prijašnje tvrdnje o tom djelu (Prolić, Kragić 2006a: 259), razjasnila je brojne metateatarske elemente u Ivšićevim djelima i Ivšićeve stavove o teatru općenito i hrvatskom kazalištu pojedinačno ${ }^{2}$ (Prolić, Kragić 2010), sistematizirala je Ivšićev prilog teoriji nadrealizma i promotrila

\footnotetext{
2 Teatra u teatru u Ivšićevu teatru dotaknula se i Lada Čale Feldman (1997).
} 
njegova djela u kontekstu nadrealizma upozoravajući na mnogobrojna simplificiranja nadrealizma te zablude oko naravi povezanosti Ivšićeva teatra s nadrealizmom s obzirom na često previđanu činjenicu da se Ivšić nadrealističkom pokretu pridružio tek nakon što je nastala većina njegova dramskog djela (Prolić 2005b). Suprotno uobičajenim podjelama Ivšićeva opusa A. Prolić zagovornica je i teze da se Ivšićevu korsku recitaciju Narcis može ubrojiti u Ivšićev dramski opus (Prolić 2005a), na što na nekoliko mjesta upućuje i sam autor (a zbog čega je Narcis i uključen u ovaj rad).

Pitanja opsega i sastava Ivšićeva dramskog korpusa javljala su se i na posve drukčijim osnovama, u prvom redu na temelju suodnosa izvornoga dramskog djela i adaptacije, kao u slučaju tročinske lutkarske igre Snjeguljica i medvjedići koju, iako igranu (1948) i tiskanu (1950) pod njegovim imenom, Ivšić smatra adaptacijom i rezolutno je izostavlja iz razgovora o svome dramskom opusu (Ivšić 2002: 144-145). Hrvatska književna i kazališna historiografija nisu se previše bavile raščlanjivanjem navedenog pitanja, tek ga prividno riješivši navođenjem Snjeguljice u popisu autorovih djela na kraju leksikonskih natuknica i izostavljanjem rasprave o njezinu sadržaju, formi i autorstvu u problemskim dijelovima teksta.

U svom se kazališnom radu Ivšić izravno bavio lutkarstvom, nadahnjivao se kazalištem lutaka i lutkom u pisanju i promišljanju vlastitog teatra. Izuzev njegova udjela u Družini mladih i u osnutku Zagrebačkog kazališta lutaka, taj je aspekt njegova djelovanja ostao razmjerno slabo istražen, pa je tako i njegov tekst Kratka povijest kazališta lutaka iz 1951. pionirski pokušaj teatrološkog rezimiranja povijesti hrvatskog lutkarstva - koliko god se iz današnje perspektive doimao manjkavim - ostao gotovo nezabilježen.

Posljednjih se godina Ivšićevo djelo našlo i u fokusu istraživača koji na njega implementiraju različite suvremene teoretske spoznaje, poput književne antropologije primjerice u radovima Lea Rafolta (2007). Osim što je, kao i A. Prolić, propitivao često apostrofiranu neporecivost pripadnosti cijeloga Ivšićeva opusa okviru nadrealizma, u njegovim se radovima Ivšićev opus sagledava u kontekstu teorija interkulturalnosti i transkulturalnosti (na tragu prethodnih povezivanja Ivšićeva djela s istočnim kazališnim tradicijama), odnosa prema povijesti i povijesnosti (Jan Kott), antimodernizma (Zoran Kravar) ili postdramskih kazališnih praksi (Hans-Thies Lehmann). U sklopu svoga viševrsnog i dugogodišnjeg bavljenja književnim nadrealizmom o Ivšiću je i na hrvatskom i na francuskom jeziku u više navrata pisala 
i izlagala prevoditeljica, esejistica i priređivačica dvosveščane antologije Francuski nadrealizam Višnja Machiedo, ponajviše u kontekstu nadrealizma te jezične osebujnosti Ivšićeva djela, „gurajući” kao i D. Gašparović u prvi plan Ivšićevu Aiaxaiu.

\section{Od osporavanja do prihvaćanja}

Od trenutka kad se Ivšić pojavio na književnoj i kazališnoj sceni u četrdesetim godinama prošlog stoljeća pa do danas, nekoliko godina nakon autorove smrti 2009. godine, može se reći da je recepcija Ivšićeva dramskog opusa u hrvatskom teatru i teatrologiji ili, preciznije rečeno, u hrvatskoj dramskoj književnosti, u hrvatskom kazalištu i u hrvatskoj književnoj i kazališnoj historiografiji prošla nekoliko stupnjeva (ne)prihvaćanja koje bismo, uz opasku da nije riječ o posve jednoznačnim, čistim i nepropusnim granicama već uvjetnim kategorijama, radi lakšeg razumijevanja mogli podijeliti u tri glavne faze.

Prva je faza zabranjivanja, odbijanja, negiranja i posvemašnjeg odbacivanja njegova dramskog djela i poklapa se ugrubo s vremenom nastanka većeg dijela njegova dramskog opusa, odnosno s četrdesetim godinama vladavine NDH i s prvim poslijeratnim godinama komunističkog režima, kada su njegova izvorna teatarska djela plijenjena, igrana u ilegali, skidana s repertoara, odbacivana za tiskanje, zabranjivana i prešućivana - pismenim i češće usmenim odlukama - iako su njegove kazališne adaptacije i prijevodi izvođeni i/lil tiskani, kao i njegov tekst o povijesti lutkarskog kazališta, a poezija tiskana u vlastitoj nakladi ili fragmentarno u nekoliko književnih časopisa poput „Krugova”.

Druga faza je faza prihvaćanja ili, točnije rečeno, toleriranja koja nastupa nakon nekoliko desetljeća šutnje, u drugoj polovici sedamdesetih i prvoj polovici osamdesetih, a poklapa se s prvim otisnutim primjercima njegova teatra, ponajprije časopisnim (Kralj Gordogan), a onda i cjelokupne dotadašnje kazališne produkcije u knjizi Teatar (1978) te s prvim uprizorenjima njegovih dramskih tekstova u profesionalnim i amaterskim ili studentskim kazalištima i kazališnim skupinama. Druga se faza dijelom podudarila s počecima afirmacije postmodernističkoga književnog modela, ali i sa smrću čelnog čovjeka režima, predsjednika Josipa Broza Tita, i književnika koji je 
velikim dijelom obilježio poslijeratni hrvatski književni, kazališni i kulturni život, Miroslava Krleže, spram kojega je Ivšić bio otvoreno kritičan, i za njegova života i nakon njegove smrti.

Posljednja ili treća faza koju možemo nazvati fazom ulaska u kanon umnogome se podudara sa slomom totalitarnog režima i osamostaljenjem Hrvatske, odnosno s potrebom da se revalorizira i (re)kanonizira povijest nacionalne književnosti i teatra s naglaskom na prevrednovanju nekih do tada marginaliziranih rukopisa, kao i s nekim novim smjerovima u znanstvenom promišljanju povijesti općenito i povijesti književnosti/kazališta zasebno.

Nesumnjivo, slučaj Radovana Ivšića velikim dijelom uzrokovan i njegovom u naslovu izdvojenom maksimom - ,nije na pjesniku da se klanja kralju" - jedinstvena je pojava u hrvatskome kulturnom prostoru, kao što je izvanserijsko bilo i njegovo književno djelovanje i opus. Neprihvaćen i neshvaćen u vrijeme kada su nastajali njegovi dramski tekstovi, velikim djelom on je bio teško prihvaćen i u vrijeme objavljivanja i igranja, bez nekoga tko bi ga slijedio ili nasljedovao njegov model jednako kao što ni sam nije imao uzora, ostajući velikim dijelom izdvojen iz korpusa hrvatske dramske književnosti i kazališta, no čini se napokon više ne i iz povijesne i teorijske refleksije o njemu.

\section{Literatura}

Anić V., 2003, Veliki rječnik hrvatskoga jezika, Zagreb.

Batušić N., 1978, Povijest hrvatskoga kazališta, Zagreb.

Bial H., Magelssen S. (ur.), 2010, Theater Historiography. Critical Interventions, Ann Arbour.

Canning Ch., Postlewait T. (ur.), 2010, Representing the Past. Essays in Performance Historiography, Iowa City.

Čale Feldman L., 1997, Teatar u teatru u hrvatskom teatru, Zagreb.

Denona J., 1996a, Teatar Radovana Ivšića, prvi dio, „Zor” br. 1, god. II, str. 117-129.

Denona J., 1996b, Teatar Radovana Ivšića, drugi dio, ,Zor” br. 2-3, god. II, str. 83-103.

Detoni Dujmić D. et al. (ur.), 2008, Leksikon hrvatske književnosti-djela, Zagreb.

Fališevac D., Nemec K., Novaković D. (ur.), 2000, Leksikon hrvatskih pisaca, Zagreb.

Gašparović D., 2012, Radovan Ivšić, u: idem, Dubinski rez, Zagreb, str. 213-235. 
Hećimović B. (ur.), 1988, Antologija hrvatske drame, sv. 3, Zagreb.

Ivšić R., 2002, Unepovrat, opet. Članci, razgovori i dokumenti 1956-2002, Zagreb.

Jelčić D., 1997, Povijest hrvatske književnosti, Zagreb.

Jelčić D., 2004, Povijest hrvatske knijževnosti, Zagreb

Lederer A., 2002, Uvodno objašnjenje hrvatskom izdanju, u: 500 drama: vodič kroz svjetsku i domaću dramsku knijževost, ur. Z. Maljković, Zagreb.

Macan T. (ur.), 2005, Hrvatski biografski leksikon. I-Kal, Zagreb.

Machiedo V., 2007, Radovan Ivšić ili igra zrcala bez kraja, u: V. Machiedo, Od kazališta do teksta i obrnuto. Romanističke i hrvatske studije i ogledi, Zagreb, str. 179-189.

Matthewsa J.H., 1974, Theatre in Dada and Surrealism, Syracuse.

Maljković Z. (ur.), 2002, 500 drama: vodič kroz svjetsku i domaću dramsku književnost, prev. M.B. Milanović, Zagreb.

Mrduljaš I., 1984, Dramski vodič, Zagreb.

Mrduljaš I., 1997, Dramski vodič od Vojnovića do Matišića, Zagreb.

Mrkonjić Z., 1975, Preobrazba farse, „Prolog” br. 26, god. VII, str. 3-11.

Novak S.P., 2003, Povijest hrvatske književnosti. Od Baščanske ploče do danas, Zagreb.

Novak S.P., 2011, Krležijanci, u: idem, Zločesti tekstovi, Zagreb, str. 85-89.

Postlewait T., 2009, The Cambridge Introduction to Theatre Historiography, New York.

Prolić A., 2005a, Igra i igranje u dramskim djelima Radovana Ivšića, u: Dani hvarskog kazališta, knj. 31, Zagreb-Split, str. 374-383.

Prolić A., 2005b, Ivšićev prilog teoriji kazališnog nadrealizma, u: Krležini dani u Osijeku 2004., prir. B. Hećimović, Zagreb-Osijek, str. 246-258.

Prolić Kragić A., 2006a, Performativnost jezika u Ivšićevom Sunčanom gradu, u: Krležini dani u Osijeku 2005, prir. B. Hećimović, Zagreb-Osijek, str. 251-261.

Prolić Kragić A., 2006b, Prostor šume (kao prostor noći) i granice vlasti (u Shakespeareovu Macbethu i Ivšićevu Kralju Gordoganu), Dani hvarskog kazališta, knj. 32, Zagreb-Split, str. 321-345.

Prolić Kragić A., 2010, Teatrom o teatru - metateatralni elementi u dramama Radovana Ivšića, „Zbornik radova Fakulteta dramskih umetnosti” br. 16, Beograd, s. 11-22.

Rafolt L., 2009, Drugo lice drugosti, Zagreb.

Senker B., 2001, Hrestomatija novije hrvatske drame, II. dio (1941-1995), Zagreb.

Visković V. (ur.), 2010-2012, Hrvatska književna enciklopedija, sv. 4, Zagreb.

Wilmer S.E. (ur.), 2004, Writing and Rewriting National Theatre Histories, Iowa City.

Worthen W.B., Holland P. (ur.), 2003, Theorizing Practice. Redefining Theatre History, New York. 
